\title{
PENGARUH BI'AH AL-'ARABIYAH TERHADAP KETERAMPILAN BERBICARA BAHASA ARAB SANTRIWATI PESANTREN AL-AMANAH LIABUKU KOTA BAUBAU
}

\author{
Ramsul Hasan \\ Kamaluddin Abu Nawas \\ Shabir U
}

\begin{abstract}
Abstrak: Penelitian ini bertujuan untuk mengetahui bagaimana lingkungan bahasa Arab (bī'ah al-'arabiyah) di Pondok Pesantren Al-Amanah, bagaimana keterampilan berbicara bahasa Arab santriwati Pesantren AlAmanah, serta untuk mengetahui seberapa besar pengaruh lingkungan bahasa Arab terhadap keterampilan berbicara bahasa Arab santriwati Pondok Pesantren Al-Amanah. Penelitian ini merupakan penelitian lapangan (field research) dengan metode kuntitatif. Sumber data penelitian ini adalah dewan guru serta santriwati Pesantren Al-Amanah. Selanjutnya metode pengumpulan data yang digunakan adalah melalui kuesioner, tes lisan serta dokumentasi. Teknik pengolahan datanya dilakukan dengan menggunakan pendekatan statistik dan selanjutnya menggunakan regresi untuk penarikan kesimpulan. Hasil penelitian ini menunjukan bahwa parstisipasi terhadap lingkungan bahasa Arab dalam kategori sedang dengan presentase $66 \%$ dari 50 responden,. Sedangkan kemampuan Bahasa arab santriwati juga dalam kategori sedang dengan pencapaian $68 \%$ dari hasil tes lisan yang dilaksanakan. Berdasarkan hasil analisis data yang dilakukan dengan menggunakan analisis regresi sederhana menunjukkan hasil uji t sebesar 7,995, signifikan pada 0,000 0,05 dengan persamaan $\mathrm{Y}^{\wedge}=94,942+0,270 \mathrm{X}$. Hal ini menunjukkan bahwa H_0 ditolak, atau H_1 diterima. Dengan demikian dapat disimpulkan bahwa lingkungan berbahasa Arab berpengaruh terhadap kemampuan berbicara santriwati di pondok Pesantren Al-Amanah Kecamatan Bungi Kota Baubau.
\end{abstract}

Keywords: Pengaruh; Bī' ah al-‘Arabiyah; Keterampilan Berbicara; Bahasa Arab

\section{PENDAHULUAN}

Bahasa pada hakikatnya merupakan suatu sistem simbol yang tidak hanya merupakan urutan bunyi-bunyi, tetapi juga memiliki makna. Bahasa juga merupakan suatu hal yang sangat penting dalam sebuah kehidupan manusia. Sebab dengan bahasa itulah, manusia dapat berkomunikasi dan menyampaikan semua gagasan dan isi pikirannya. Bahasa merupakan suatu sarana yang sangat penting dalam menyampaikan suatu ide maupun pesan. Melalui bahasa kita dapat berkomunikasi dan mengetahui perkembangan yang terjadi. Bahasa sebagai sesuatu hasil karya cipta manusia memiliki peran yang sangat penting dalam interaksi antara sesama manusia. Bahasa menandai eksistensi manusia, sehingga dapatlah dikatakan "aku berbahasa karena aku hidup". 
Gorys keraf menyebutkan bahwa bahasa adalah alat komunikasi antara anggota masyarakat berupa simbol bunyi yang dihasilkan oleh alat ucap manusia. Selain itu, bahasa merupakan alat komunikasi untuk menyampaikan gagasan, pikiran, maksud, dan tujuan kepada orang lain. Bahasa merupakan perantaraan seseorang mengungkapkan apa yang tampak terpendam dalam perasaannya.Bahkan seseorang mampu menyampaikannya kepada orang lain melalui bahasa. Selain itu, bahasa merupakan perantaraan seseorang yang dapat memberi nama kepada benda-benda.

Bahasa merupakan alat komunikasi yang penting dalam kehidupan manusia. Sebagaimana dikemukan oleh Roqib bahwa secara kronologis fungsi bahasa adalah untuk menyatakan ekspresi diri, alat komunikasi, alat untuk mengadakan integrasi dan adaptasi sosial dan sebagai alat untuk kontrol sosial. Dengan bahasa, seseorang akan melakukan komunikasi, baik ketika ia akan menyampaikan sesuatu yang ada dalam benaknya maupun menerima kabar dari orang lain

Bahasa Arab merupakan salah satu bahasa yang telah menyentuh berbagai ranah dunia. Selain sebagai bahasa media ajaran islam, bahasa Arab juga telah berjasa dalam menjunjung tinggi sains dan teknologi, memperkaya khazanah budaya nasional dan media perubahan politik internasional yang semakin menampakkan peranannya dewasa ini. Sehingga bahasa Arab mengalami perkembangan yang sangat pesat.

Bahasa Arab merupakan salah satu bahasa mayor di dunia yang dituturkan oleh lebih 200.000.000 umat manusia di dunia dan bahasa ini juga digunakan lebih dari 20 negara. Bahasa Arab juga telah diakui peranannya oleh lembaga internasional sebagai bahasa komunikasi dunia secara resmi.

Bahasa Arab adalah bahasa yang digunakan sebagai bahasa ilmu pengetahuan dan komunikasi. Bahasa Arab, di samping sebagai bahasa internasional, juga telah menjadi bahasa resmi di Perserikatan Bangsa-bangsa. Lebih dari itu bahasa Arab adalah bahasa al-Qur'an, hadis, bahasa ibadah bagi umat Islam dan digunakan dalam penulisan berbagai literatur ilmu pengetahuan keislaman. Oleh karena itu, mempeserta didiki bahasa Arab bagi umat Islam mutlak adanya untuk memahami dan mendalami berbagai ilmu pengetahuan keislaman yang semuanya bersumber dari al-Qur'an dan hadis. Mu'jizat dan kandungan al-Qur'an kurang dapat dipahami, diresapi dan dihayati tanpa mengetahui dan memahami bahasa Arab, karena al-Qur'an tidak dapat dituangkan ke dalam bahasa lain sebagai gantinya.Karena itu, mempeserta didiki bahasa Arab mutlak adanya.

Firman Allah swt. dalam QS. Al-Zukhruf /43:3

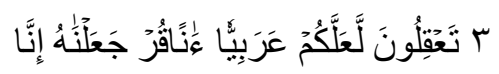


Terjemahnya:

"Sesungguhnya Kami menurunkan al- Quran dalam bahasa Arab supaya kamu memahaminya."

Bahasa Arab telah berjasa memajukan sains dan filsafat sekitar abad ke-7 saat kejayaan kerajaan Islam Abasiyah mencapai puncaknya. Kejayaan itu ditandai dengan meningkatnya produktivitas karya ilmiah dan filsafat yang dimotori oleh para ilmuwan dan filosof muslim, baik karangan asli menggunakan bahasa Arab maupun terjemahan Barat-Arab dan Arab-Barat, antara lain di bidang matematika, fisika, kimia, kedokteran, astronomi, kesastraan, dan filsafat.

Bahasa Arab sebagai salah satu bahasa dunia, mempunyai kedudukan yang tinggi setelah bahasa Inggris, yaitu sebagai bahasa internasional. Bahasa Arab telah resmi digunakan sebagai "bahasa penghubung" antar bangsa, karena bahasa Arab merupakan: (1) bahasa resmi bagi 20 negara di benua Asia dan Afrika, (2) bahasa resmi di lingkungan Perserikatan Bangsa-bangsa, (3) bahasa resmi dalam organisasi- organisasi Islam internasional, seperti Muktamar alIslamiyah, Rabitah Alam Islami, dan Organisasi Islam Internasional (OII) yang berpusat di Jakarta, (4) bahasa resmi dalam konferensi-konferensi Islam Internasional yang Indonesia menjadi anggotanya, (5) sebagai bahasa penghubung antar negara Indonesia dan negara-negara Arab, karena pada zaman yang dewasa ini hubungan antar bangsa Indonesia dan bangsa-bangsa Arab semakin meningkat dan luas, baik di bidang agama, ekonomi, pendidikan, kebudayaan dan politik.

Sebagaimana bahasa yang lain, bahasa Arab memiliki fungsi sebagai alat komunikasi, transfer, dan menyatakan seseorang baik secara lisan maupun tulisan. Sesuatu yang ditransfer biasa berupa pemikiran, pengertian, perilaku dan kesenangan atau secara global yang ditransfer adalah pemikiran Salah satu karakteristik bahasa tak terkecuali bahasa Arab, bahwa bahasa tersebut tumbuh kembang dan tidak stagnan, baik dalam tatanan personal, maupun sosial. Secara personal, bahasa dapat berkembang bersamaan dengan bertambahnya usia dan pengalaman pemakainya. Sedangkan secara sosial, bahasa dapat berekembang melalui interaksi dan komunukasi antar pemakai bahasa Berdasarkan fungsi bahasa tersebut, maka tujuan pembelajaran suatu bahasa hendaklah berarti melatih kebiasaan ataun otomatisasi fungsi pendengaran, pengertian tentang apa yang didengar dan dibaca, pengutaraan pendapat sekaligus menuliskannya. Namun dalam operasionalnya, tugas merealisaikan tujuan pembelajaran, bukanlah hal yang mudah, di mana dalam prosesnya terdapat berbagai macam kesulitan, baik dari faktor akademis maupun nonakademis.

Perkembangan pendidikan bahasa Arab di Indonesia telah melalui masa yang sangat lama.Dapat dipastikan bahwa bahasa Arab masuk di Indonesia bersamaan dengan masuknya agama Islam di negara ini, karena kaitannya sebagai bahasa yang digunakan dalam berbagai ritual keagamaan dan bahasa AlQur'an 
Bahasa Arab di Indonesia umumnya dipeserta didik di madrasah dan pesantren, walaupun ada pula lembaga pendidikan umum yang mempeserta didikinya. Bahasa Arab menjadi salah satu mata peserta didikan yang tergolong sangat penting dan harus diperhatikan. Setidaknya ada dua alasan yang mendasarinya.Pertama, bahasa Arab merupakan bahasa komunikasi internasional yang harus dipeserta didiki bila ingin bergaul dengan orang atau mempeserta didiki kultur budaya masyarakat yang menggunakan bahasa Arab sebagai bahasa sehari-hari. Kedua, bahasa Arab adalah bahasa agama Islam. Hal ini merupakan motivasi utama bagi kaum muslim untuk memahami ajaran-ajaran agama Islam. Mereka merasa harus mempelajarinya demi menuju kesempurnaan amal ibadah. Bagi mereka adalah sesuatu yang sangat penting untuk mempelajari bahasa Arab dalam berbagai kemampuannya dan selanjutnya mengetahui, memahami dan mendalami ajaran Islam yang bersumber dari al-Qur'an dan hadis, di mana keduanya berbahasa Arab. Hal ini sebagaimana yang diungkapkan oleh Hillary Wise: "As the language of the Koran, the holy book of Islam, Arabic is taught as a second language in muslim states throughout the world."

Lingkungan bahasa Arab sangat mendukung untuk menunjang kemahiran bahasa Arab. Belajar bahasa akan lebih mudah bila terjadi dengan penguatan dan terdapat pengulangan terus menerus sehingga membentuk sebuah kebiasaan, karena pada prinsipnya bahasa adalah kebiasaan. Proses penguatan ini dapat dilakukan dengan lingkungan bahasa, baik lingkungan buatan maupun berbentuk alami sehigga seorang peserta didik secara tidak langsung mendapatkan kemahiran.

Bahasa Arab menjadi salah satu bahasa asing yang telah diajarkan di hampir seluruh sekolah di Indonesia, khususnya sekolah-sekolah berbasis Islam seperti madrasah dan pondok pesantren.Pendidikan bahasa Arab telah mengalami perkembangan dari masa ke masa sesuai dengan kemajuan zaman dan teknologi. Perkembangan teknologi sebagai media diciptakan untuk meningkatkan kemahiran berbahasa Arab peserta didik. Sebab keberhasilan peserta didik memahami kaidah, membaca dan menulis serta menerapkannya dalam komunikasi baik lisan maupun tulisan, merupakan tolok ukur bagi pendidik bahwa tujuan pembelajaran bahasa telah tercapai. Hal ini karena bahasa Arab merupakan pelajaran bahasa asing yang tidak dapat terlepas dari kesulitankesulitan dan problem-problem dalam pembelajarannya.

Suatu hal yang tidak terlepas dalam wacana pendidikan di Indonesia adalah Pondok Pesantren. Pondok pesantren adalah pendidikan pertama dan tertua di Indonesia. Keberadaannya mengilhami model dan sistem-sistem yang ditemukan saat ini. Pondok pesantren bahkan tidak lapuk dimakan zaman dengan segala perubahannya. Karenanya banyak pakar, baik lokal maupun internasional melirik pondok pesantren sebagai bahan kajian. Tidak jarang beberapa tesis dan disertasi menulis tentang lembaga pendidikan Islam tertua ini.

Di antara sisi yang menarik para pakar dalam mengkaji lembaga ini sejak dilancarkannya perubahan atau modernisasi pendidikan Islam di berbagai 
kawasan dunia muslim, tidak banyak lembaga-lembaga pendidikan tradisional Islam separti pesantren yang mampu bertahan disamping karena "modelnya" . Sifat ke-Islaman dan ke-Indonesiaan yang terintegrasi dalam pesantren menjadi daya tariknya. Belum lagi kesederhanaan, sistem, dan manhaj yang terkesan apa adanya, hubungan Kyai dan Santri serta keadaan fisik yang serba sederhana. Walau di tengah suasana yang demikian, yang menjadi magnet terbesar adalah peran dan kiprahnya bagi masyarakat, negara, dan umat manusia yang tidak bisa dianggap tidak berpengaruh atau dilihat sebelah mata. Sejarah membuktikan besarnya konstribusi yang pernah dipersembahkan lembaga yang ini, baik di masa pra kolonial, kolonial, dan pasca kolonial, bahkan di masa kini pun peran itu masih tetap dirasakan.

Pondok pesantren, menurut sejarah akar berdirinya di Indonesia, ditemukan dua versi pendapat. Pertama, menyebutkan bahwa pondok pesantren berakar pada tradisi Islam itu sendiri, yaitu tradisi tarekat. Pendapat kedua mengatakan bahwa pondok pesantren yang dikenal sekarang ini pada mulanya merupakan pengambilalihan dari sistem pondok pesantren yang diadakan orangorang Hindu di Nusantara. Hal ini didasarkan pada fakta bahwa jauh sebelum datangnya Islam ke Indonesia, lembaga pondok pesantren sudah ada di negeri ini. Pendirian pondok pesantren pada masa itu dimaksudkan sebagai tempat mengajarkan ajaran-ajaran agama Hindu. Fakta lain yang menunjukkan bahwa pondok pesantren bukan berasal dari tradisi Islam adalah tidak ditemukannya lembaga pondok pesantren di negara-negara Islam lainnya.

Pondok pesantren di Indonesia baru diketahui keberadaan dan perkembangannya setelah abad ke-16. Karya-karya Jawa klasik seperti Serat Cabolek dan Serat Centini mengungkapkan bahwa sejak permulaan abad ke-16 ini di Indonesia telah dijumpai lembaga-lembaga yang mengajarkan berbagai kitab Islam klasik dalam bidang fikih, aqidah, tasawuf dan menjadi pusat-pusat penyiaran Islam yaitu pondok pesantren.

Pada dasarnya, pondok pesantren lahir sebagai perwujudan dari dua keinginan yang bertemu. Keinginan orang yang ingin menimba ilmu sebagai bekal hidup (santri) dan keinginan orang yang secara ikhlas mengajarkan ilmu dan pengalamannya kepada umat (kyai). Adapun tempatnya dapat berupa langgar, mushalla atau mesjid, yang berkembang berdasarkan bertambahnya santri yang menuntut ilmu

Terlepas dari perbedaan asal mula terbentuknya pondok pesantren, bila dilihat kembali sejarah kemerdekaan bangsa Indonesia ini, maka pondok pesantren tidak hanya sebagai lembaga pendidikan yang mengajarkan moral kepada santri-santri dan masyarakat Indonesia, namun mereka juga sangat berperan penting dalam membantu mengantarkan bangsa Indonesia kepada kemerdekaannya. Kiyai dan santri selalu berjuang baik dalam membina masyarakat maupun dalam mengangkat senjata melawan penjajah.

Sejarah tersebut membuktikan bahwa pondok pesantren merupakan lembaga pendidikan yang lahir dari masyarakat Indonesia itu sendiri. Oleh karena 
itu, lembaga pendidikan Islam ini perlu dipertahankan eksistensinya dan dikembangkan agar tidak ketinggalan zaman ataupun punah sama sekali. Bahkan, lembaga pendidikan Islam seperti ini direspon, dan tidak dipandang sebelah mata oleh masyarakat, karena pondok pesantren merupakan pengembangan amanat sebagai salah satu sarana pengkajian ilmu agama bagi umat Islam yang ingin mendalaminya.

Firman Allah swt. dalam QS al-Taubah/9: 122

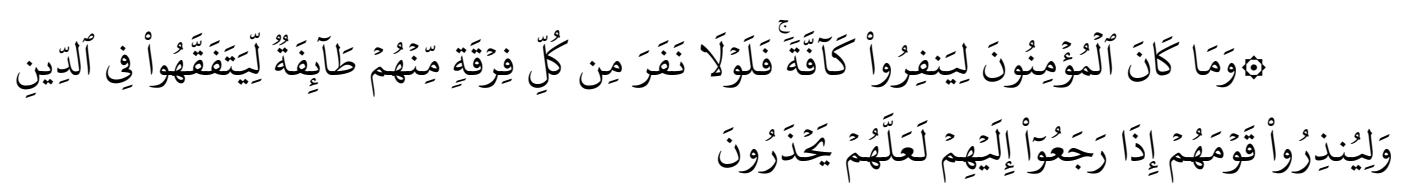

Terjemahnya:

"Dan tidak sepatutnya orang-orang mukmin itu semuanya pergi (ke medan perang). Mengapa sebagian dari setiap golongan di antara mereka tidak pergi untuk memperdalam pengetahuan agama mereka dan untuk memberi peringatan kepada kaumnya apabila mereka telah kembali agar mereka dapat menjaga dirinya."

Dari terjemahan ayat tersebut bisa dipahami bahwa memperdalam ilmu agama dianjurkan pada sebagian manusia agar dapat menjadi teladan di tengahtengah masyarakat yang memiliki beragam profesi, sekaligus sebagai penasehat bila ada yang melanggar aturan Tuhan.

Penggunaan bahasa asing yaitu Arab dan Inggris dalam pondok pesantren modern dianggap sangat penting, karena bahasa asing dipandang mampu meningkatkan kualiatas pembelajaran di pondok modern, bahkan mampu meningkatkan kualitas peserta didik. Hal itu pula yang terapkan di dalam pondok pesantren Al-Amanah.

Pondok Pesantren Al-Amanah adalah pondok pesantren yang memadukan pembelajaran ilmu pengetahuan agama dan ilmu pengetahuan umum. Adapun penggunaan bahasa asing yaitu Arab dan Inggris adalah suatu kewajiban yang harus dijalankan setiap santriwati di Pondok Pesantren Al-Amanah. Penggunaan bahasa asing, pada setiap santriwati Al-Amanah dianggap sangat membantu proses pembelajaran dan meningkatkan kualitas mutu santriwati Pondok pesantren.

Berdasarkan penjelasan tersebut, pengelolaan lingkungan bahasa dianggap sangat penting bagi santriwati Pesantren Al-Amanah dalam meningkatkan kualitas bahasa Arab. Dengan demikian, pengkajian terhadap pengelolaan lingkungan bahasa perlu dilakukan untuk melihat pengaruh penggunaan metode tersebut dalam meningkatkan kualitas bahasa Arab.

Untuk mencapai tujuan tersebut, Pesantren Al-Amanah menciptakan lingkungan bahasa, karena lingkungan bahasa merupakan sarana yang dapat meningkatkan dan mengembangkan aktivitas berbahasa peserta didik agar 
terkoordinir, maka diharapkan dapat menciptakan bì'ah al-lugawiyyah yang kondusif dan humanis, karena pemakaian kata dan struktur bahasa yang terjadi dalam lingkungan bahasa akan mempengaruhi perkembangan bahasa.

Berdasarkan urain diatas makapemilihan Pondok Pesantren Al-Amanah sebagai objek penelitian disebabkan karena Pondok Pesantren Al-Amanah adalah salah satu pondok pesantren yang menerapkan penggunaan dua bahasa (bahasa Arab dan bahasa Inggris) sebagai bahasa komunikasi sehari-hari, dan belum ditemukan penelitian yang menggambarkan tentang pengaruh lingkungan bahasa Arab terhadap keterampilan berbicara santriwati di pondok pesantren AlAmanah. Sehinggan dengan penelitian ini diharapkan dapat menambah khasanah ilmu pengetahuan di bidang pendidikan pada umumnya dan pengembangan ilmu pengetehuan serta dapat dipakai sebagai bahan penelitian lebih lanjut. Adapun tujuan penelitian ini adalah untuk mengetahui bagaimana lingkungan bahasa Arab (bỉ'ah al-'arabiyah) di Pondok Pesantren Al-Amanah, bagaimana keterampilan berbicara bahasa Arab santriwati Pesantren Al-Amanah, serta untuk mengetahui seberapa besar pengaruh lingkungan bahasa Arab terhadap keterampilan berbicara bahasa Arab santriwati Pondok Pesantren Al-Amanah.

\section{METODOLOGI PENELITIAN}

a. Jenis Penelitian

Jenis penelitian adalah penelitian lapangan (field research) dengan metode kuantitatif, ${ }^{1}$ dalam bentuk deskriptif regresi dan korelasi. Penelitian regresi dan korelasi adalah suatu penelitian yang melibatkan pengumpulan data guna menentukan apakah ada hubungan antara dua variabel atau lebih. Penelitian ini juga dianggap diskriptif karena penelitian ini berusaha menggambarkan dan menguraikan fakta-fakta yang terjadi pada obyek penelitian dan menganalisisnya dalam angka-angka yang diwujudkan dalam presentase sehingga memperoleh hasil penelitian. Sedangkan untuk mencari hubungan maupun prediksi, peneliti menggunakan hipotesis sebagai petunjuk dalam pemecahan masalah penelitian.

b. Waktu dan Tempat Penelitian

Penelitian dilaksanakan pada bulan Januari sampai bulan Mei tahun 2018 di Pondok pesantren Al-Amanah yang terletak di Kelurahan Liabuku Kecamatan Bungi Kota Baubau Sulawesi Tenggara. Dengan luas lahan $50.000 \mathrm{M}^{2}$, dengan status kepemilikan swasta dibawah naungan Yayasan Wakaf Al-Amanah Darussalam Liabuku. Pesantren Al-Amanah didirikan oleh KH.M.Syahruddin Saleh,MA pada tahun 2000 dan memulai proses penerimaan santriwati baru pada tahun ajaran 2001-2002. Dasar pengambilan lokasi memberi relevansi dalam melakukan penelitian untuk mengetahui pengaruh lingkungan bahasa Arab terhadap keterampilan berbicara bahasa Arab santriwati Pondok Pesantren Al-Amanah Kota Baubau. 
c. Populasi dan Sampel Penelitian

Adapun populasi dalam penelitian ini adalah semua siswa pondok pesantren AlAmanah tahun pelajaran 2017/2018 yang terdiri dari 401. Mengingat jumlah populasi yang besar di atas, maka dapat diperkecil untuk dijadikan sampel. Menurut Suharsimi Arikunto; apabila subjek kurang dari 100 orang lebih baik diambil semua sehingga peneliti merupakan penelitian populasi, selanjutnya jika jumlah subjeknya besar dapat diambil $10-15 \%$ atau $20-25 \%{ }^{2}$. Dengan asumsi yang diungkapkan Arikunto tersebut maka peneliti menggunakan pendekatan $12 \%$ dari 401 yaitu $=48$ orang dan digenapkan menjadi 50 orang santriwati. Sehingga telah ditetapkan sampel santriwati 50 orang dari keseluruhan kelas yang hendak diteliti.

\section{d. Data, Instrumen, dan Tehnik Pengumpulan Data}

Dalam upaya pengumpulan data yang akurat mengenai variabel-variabel yang akan dipelajari, maka peneliti menggunakan beberapa teknik pengumpulan data yaitu sebagai berikut: (1) kuesioner (angket); Kuesioner merupakan tekhnik pengumpulan data yang dilakukan guna memperoleh data tentang lingkungan bahasa Arab dengan cara memberi seperangkat pertanyaan atau pernyataan tertulis kepada santriwati pondok pesantren Al-Amanah untuk menjawabnya angket ini diberikan kepada 50 orang dari populasi yang ada. Angket lingkungan bahasa terdiri atas 34 pernyataan yang terbagi dalam tiga indikator dengan berbagai aspek yaitu santriwati (kegemaran, ketekungan, dan rasa ingin tahu) terdiri atas 11 pernyataan, ustaz/ustazah (bimbingan, pemberian motovasi dan hukuman) terdiri atas 6 pernyataan, dan kegiatan pendukung dan metrial pendukung (kewajiban berbahasa arab, pembentukan kelompok belajar penyediaan sarana dan prasarana berbahasa arab) terdiri atas 17 pernyataan. Setiap pertanyaan pada masing-masing angket bersifat tertutup yang dilengkapi dengan empat pilihan jawaaban yang terdiri atas: sangat setuju (SS), setuju (S), tidak setuju (TS), dan sangat tidak setuju (STS) ; (2) wawancara/tes lisan; Wawancara merupakan sebuah percakapan antara dua orang atau lebih di mana pertanyaan-pertanyaan diajukan peneliti pada obyek atau kelompok obyek penelitian untuk dijawab. ${ }^{3}$ Instrumen tes lisan yang digunakan berupa tes uaraian terdiri dari 10 item pertanyaan yang dibentuk berdasarkan kisi-kisi yang ada. Setiap pertanyaan pada soal uraian diberi skor penilaian 1-5 dengan ketentuan sangat baik, baik, cukup, kurang, dan sangat kurang dengan bobot berturut-turut 5, 4, 3, 2, dan 1 .

\section{e. Keabsahan Data}

Keabsahan data dalam penelitian ini hanya ditekankan pada uji validitas dan reliabilitas. Hasil pengujian (uji coba) digunakan sebagaai dasar untuk mempertimbangkan keberadaan instrumen, misalnya digugurkan atau dipertahankan dengan beberapa perubahan. Dalam penelitian ini instrumen yang telah diujicobakan meliputi: angket lingkungan bahasa dan soal uraian kemampuan lisan bahasa arab santriwati pondok pesantren Al-Amanah. Adapun tujuan uji coba instrumen yaitu untuk mengetahui validitas (kesahihan) dan reliabilitas (keandalan/ketepatan) instrumen penelitian sebagai syarat bagi suatu instrumen yang layak digunakan dalam penelitian. Validitas instrumen merupakan suatu hal yang sangat penting dalam pengukuran terutama terhadap instrumen yang dikembangkan sendiri oleh peneliti. Ariunto berpendapat bahwa 
sebuah instrumen yang baik dalam arti dapat mengungkapkan data dari variabel yang iteliti secara tepat.

Dalam pengujian butir pertanyaan yang telah disusun terlebih dahulu diadakan uji coba instrumen, kemudian dilakukan analisis butir instrumen dengan mengkorelasikan skor butir pertanyaan dengan skor butir total instrumen tersebut. Dalam keperluan pengukuran validitas butir instrumen digunakan rumus korelasi Product Moment dari Pearson Corelatiaon dengan ketentuan $\left(r_{\text {hitung }}>r_{\text {tabel }}\right)$ dengan mengunakan bantuan SPSS. Berdasarkan hasil analisis validitas angket dapat dilihat bahwa nilai K-M-O Measure of sampling sebesar $0,533^{-} 0.5$ dan Pearson Correlationpada tiap item secara keseluruhan menunjukkan $>\boldsymbol{r}_{\text {tabel }}=\mathbf{0 , 2 7 9}$. sehingga dapat disimpulkan bahwa semua item pernyataan angket variabel (X) lingkungan bahasa Arab dapat dinyatakan valid. Instrumen dinyatakan valid jika nilai MSA Anti-Image Correlation> 0,50. Dari 10 item pertanyaan tentang kemampuan berbicara akan dilakukan uji validitas terhadap 50 responden. Berdasarkan hasil analisis validitas angket dapat dilihat bahwa nilai K-M-O Measure of sampling sebesar $0,54^{-} 0,5$ dan Pearson Correlationpada tiap item secara keseluruhan menunjukkan $>\boldsymbol{r}_{\text {tabel }}=\mathbf{0 , 2 7 9}$, sehingga dapat disimpulkan bahwa semua item Soal variabel (Y) kemampuan berbicara bahasa Arab dapat dinyatakan valid. Sedangkan reliablitas instrumen penelitian ditunjukkan dengan angka koefisien reliabilitas instrumen yang menggunakan rumus Alpha Crombach melalui bantuan SPSS dengan ketentuan alpha cronbach $>0,60$. Berdasarkan hasil analisis reliabilitas angket dan soal uraian dapat dilihat bahwa nilai alpha cronbach kedua variabel tersebut berturut-turt sebesar 0,825 $>0,60$ dan 0,707 $>0,60$. Hal ini menunjukkan bahwa intrumen angket variabel $(\mathrm{X})$ dinyatakan reliabel.

\section{f. Teknik Analisis Data}

Pengujian data dengan menggunakan teknik analisis statistic, harus memenuhi persyaratan, diantaranya yaitu: (a) normalitas data dan (b) linearitas data. Pada penelitian ini uji prasyarat analisis meliputi uji normalitas dan uji linearitas. Uji normalitas digunakan untuk mengetahui apakah sampel dalam penelitian ini berasala dari populasi yang berdistribusi normal. Uji normalitas menggunakan uji Kolmogorov-Smirnov. Sedangkan Uji linearitas bermaksud untuk mengetahui apakah sebaran data yang diuji mempunyai sebaran yang sesuai dengan garis linier atau tidak. Untuk pengujian linieritas digunakan diagram scatterdan garis best fit. Variabel bebas dan terikat dikatakan berpengaruh secara linier apabila dibuat scatter diagram dari masing-masing nilai variabel bebas dan terikat dapat ditarik garis lurus pada pancaran titik kedua nilai variabel tersebut. Kedua pengujian prasyarat tersebut menggunakan bantuan program komputer SPSS 16.0 for windows. Setelah dilakukan uji normalitas dan linearitas, dilanjutkan dengan analisis statistik deskriptif dan inferensial. Analisis statistic deskriptif digunakan untuk mendeskriptifkan karakteristik responden pada stiap variabel. Untuk keperluan tersebut akan digunakan tabel distribusi frekuensi dan persentase yang dilengkapi dengan diagram. Sedangkan analisis inferensial digunakan untuk menguji hipotesis.

Setelah pengujian prasyarat analisis terpenuhi, selanjutnya dilakukan pengujian hipotesis. Maksud dilakukan pengujian hipotesis adalah untuk menarik kesimpulan apakah hipotesis penelitian yang dirumuskan didukung atau tidak didukung, oleh data empirik yang diambil. Pengujian analisis regresi sederhana yang meliputi uji keberartian dan uji kelinearan menggunakan uji F. untuk persyaratan analisis ini, sampel yang bersifat acak dan ukuran sampel minimum telah terpenuhi. Persyarat untuk uji ini, mengenai populasi berdistribusi normal telah dipenuhi. Kemudian untuk uji keberartian 
koefisien korelasi menggunakan uji t dalam hal ini uji hipotesis. Persyaratan uji hipotesis yaitu:

Ha: $\rho \neq 0$; Ada pengaruh yang signifikan antara lingkungan Bahasa Arab terhadap kemampuan berbicara bahasa Arab

Ho: $\rho=0$; Tidak ada pengaruh yang signifikan antara lingkungan bahasa Arab terhadapkemampuan berbicara bahasa Arab

\section{HASIL PENELITIAN DAN PEMBAHASAN}

\section{a. Lingkungan Bahasa Arab}

Hasil pengumpulan data diperoleh skor empirik mengenai lingkungan bahasa arab secara keseluruhan didapatkan rentang nilai antara 67-122, harga ratarata 88,6000, median sebesar 88,5000, mode atau modus sebesar81,00, standar deviasi sebesar 11,87864, nilai minimum sebesar 67,00, nilai maksimum sebesar 120,00 , dan jumlah atau sum sebesar 4430,00. Berdasarkan hasil pengolahan di atas dapat diketahui bahwa rata-rata responden menjawab kuesioner sekitar 88,6, hal ini menunjukkan jawaban responden relative baik. Distribusi frekunsi serta grafik histogram dipaparkan di bawah ini:

\begin{tabular}{cccc}
\multicolumn{4}{c}{ Tabel 1.Distribusi Frekuensi Lingkungan Bahasa Arab } \\
\cline { 2 - 4 } No & Interval & Frekuensi & Prosentase (\%) \\
\hline 1. & $67-74$ & 8 & 16 \\
2. & $75-82$ & 9 & 18 \\
3. & $83-90$ & 12 & 24 \\
4. & $91-98$ & 10 & 20 \\
5. & $99-106$ & 9 & 18 \\
6. & $107-114$ & 1 & 2 \\
7. & $115-122$ & 1 & 2 \\
\hline & Jumlah & $\mathbf{5 0}$ & $\mathbf{1 0 0}$
\end{tabular}

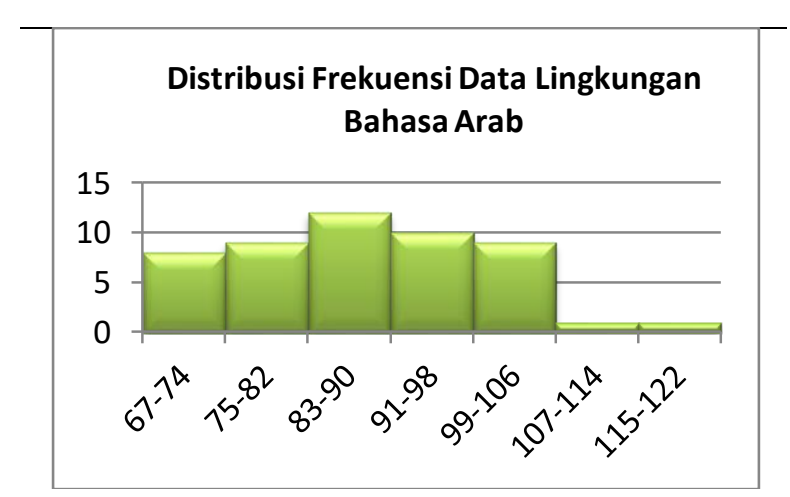

Gambar 1. Histogram Distribusi Frekuensi Lingkungan Bahasa Arab 
Selanjutnya, pengkategorian kecenderungan variabel lingkungan bahasa Arab digolongkan ke dalam 3 kategori kecenderungan variabel, yaitu tinggi, sedang, dan rendah. Berdasarkan nilai rata-rata atau mean dan standar deviasi, maka masing-masing kategori dapat dilihat pada Tabel 2 berikut.

Tabel 2.Kategori Skor Variabel (X) Lingkungan Bahasa Arab

\begin{tabular}{cccc}
\hline No & Skor & $\begin{array}{c}\text { Persentas } \\
\text { e (\%) }\end{array}$ & Kategori \\
\hline 1 & $100,47864<\mathrm{X}$ & 18 & Tinggi \\
2 & $100,47864 \leq \mathrm{X} \leq 76,7214$ & 66 & Sedang \\
3 & $\mathrm{X}<76,7214$ & 16 & Rendah \\
\hline
\end{tabular}

Dari Tabel 2 di atas, nampak bahwa 9 atau 18\% responden berada dalam kategori tinggi, 33 atau 66\% responden berada pada kategori sedang, dan 8 atau $16 \%$ responden berada pada kategori rendah. Berdasarkan hal itu, dapat digambarkan dengan diagram lingkaran sebagai berikut:

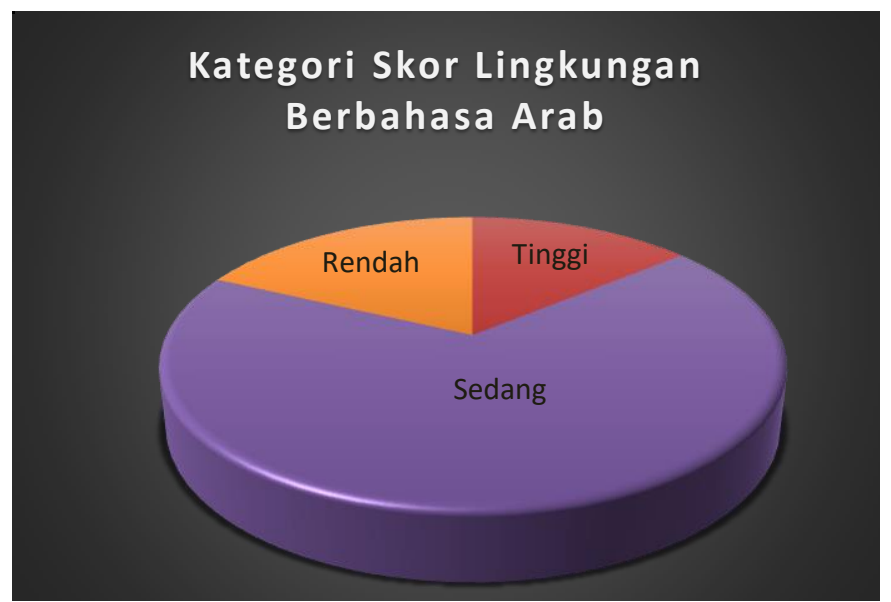

Gambar 2. Diagram Kategori Lingkungan Berbahasa Arab

b. Kemampuan Berbicara Bahasa Arab

Hasil pengumpulan data diperoleh skor empirik mengenai Kemampuan berbicara bahasa Arab secara keseluruhan didapatkan rentang nilai antara 48-96, harga rata-rata 71,04 median sebesar 70,0000, mode atau modus sebesar 68,00, standar deviasi sebesar 11,39452, nilai minimum sebesar 48,00, nilai maksimum sebesar 96,00, dan jumlah atau sum sebesar 3552,00. Berdasarkan hasil pengolahan di atas dapat diketahui bahwa rata-rata responden menjawab kuesioner sekitar 71,04,6, hal ini menunjukkan jawaban responden relatif baik. Distribusi frekunsi serta grafik histogram dipaparkan di bawah ini:

Tabel 3.Distribusi Frekuensi Kemampuan Berbicara

\begin{tabular}{cccc}
\hline No & Interval & Frekuensi & Prosentase (\%) \\
\hline 1. & $48-54$ & 4 & 8
\end{tabular}




\begin{tabular}{lccc}
2. & $55-61$ & 5 & 10 \\
3. & $62-68$ & 12 & 24 \\
4. & $69-75$ & 13 & 26 \\
5. & $76-82$ & 9 & 18 \\
6. & $83-89$ & 2 & 4 \\
7. & $90-96$ & 5 & 10 \\
\hline & Jumlah & 50 & 100 \\
\hline
\end{tabular}

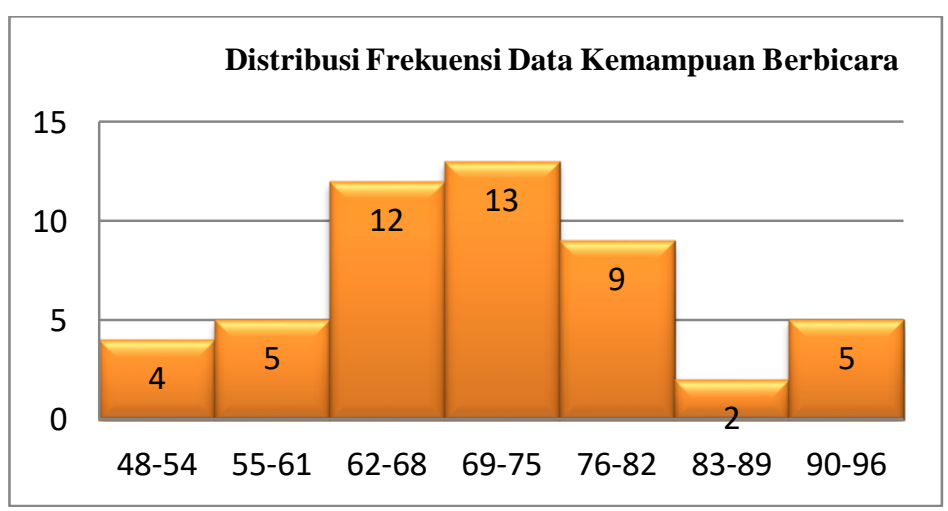

Gambar 3. Histogram Distribusi Frekuensi Data Kemampuan Berbicara

Selanjutnya, pengkategorian kecenderungan variabel lingkungan bahasa Arab digolongkan ke dalam 3 kategori kecenderungan variabel, yaitu tinggi, sedang, dan rendah. Berdasarkan nilai rata-rata atau mean dan standar deviasi, maka masing-masing kategori dapat dilihat pada Tabel 4 berikut.

\begin{tabular}{c|c|c|c}
\multicolumn{4}{c}{ Tabel 4.Kategori Skor Kemampuan Berbicara } \\
\hline No & Skor & $\begin{array}{c}\text { Persentas } \\
\text { e }(\%)\end{array}$ & $\begin{array}{c}\text { Kategor } \\
\mathrm{i}\end{array}$ \\
\hline 1 & $82,43452<\mathrm{X}$ & 14 & Tinggi \\
2 & $82,43452 \leq \mathrm{X} \leq 59,64548$ & 68 & Sedang \\
3 & $\mathrm{X}<59,64548$ & 18 & Rendah \\
\hline
\end{tabular}

Dari Tabel 4 di atas, nampak bahwa 7 atau 14\% responden berada dalam kategori tinggi, 34 atau 68\% responden berada pada kategori sedang, dan 9 atau $18 \%$ responden berada pada kategori rendah. Berdasarkan hal itu, dapat digambarkan dengan diagram lingkaran sebagai berikut: 


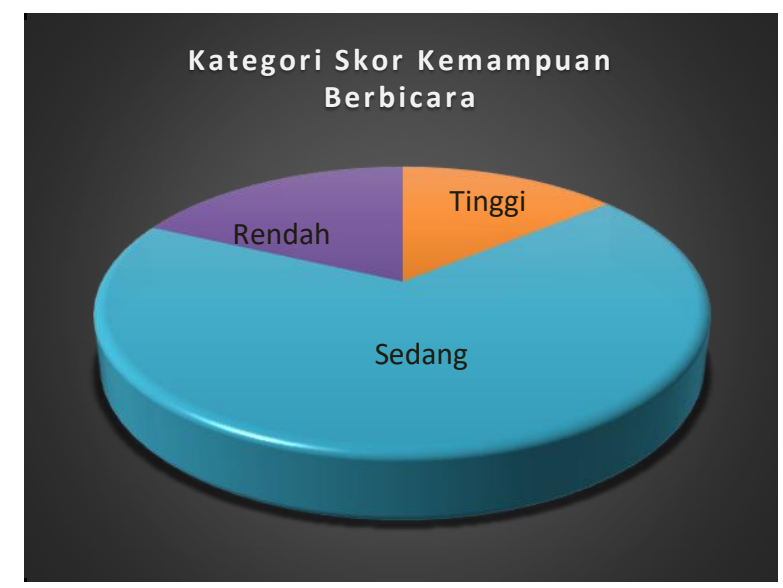

Gambar 4. Diagram Kategori Kemampuan Berbicara

c. Pengujian Persyaratan Analisis

Sebelum melakukan pengujian hipotesis penelitian, terlebih dahulu dilakukan uji normalitas sampel dan uji linearitas data. Pengujian ini dimaksudkan untuk memperoleh informasi mengenai kedua hal tersebut sebagaimana dipaparkan pada halaman berikut.

1) Pengujian Normalitas

Data yang akan diuji kenormalannya adalah data variabel terikat yaitu keterampilan berbicara bahasa $\operatorname{arab}(\mathrm{Y})$, serta data variabel bebas yaitu lingkungan bahasa Arab (X). Untuk menentukan statistic yang akan digunakan dalam analisis data ini diperlukan pengujian persyaratan analisis dalam bentuk pengujian normal tidaknya data. Uji yang digunakan dikenal dengan nama One-Sample Kolmogrov-Smirnov dengan menggunakan taraf signifikasi 0,05 . Data dinyatakan berdistribusi normal jika signifikasi lebih besar dari $5 \%$ atau 0,05 . Berdasarkan hasil perhitungan dengan menggunakan bantuan IBM SPSS Statistics 16, diperoleh data sebagai berikut:

Tabel 5 Uji Normalitas Angket

One-Sample Kolmogorov-Smirnov Test

\begin{tabular}{|c|c|c|}
\hline & & VAR00001 \\
\hline $\mathrm{N}$ & & 50 \\
\hline \multirow[t]{2}{*}{ Normal Parameters ${ }^{\mathrm{a}, \mathrm{b}}$} & Mean & 88.6000 \\
\hline & $\begin{array}{l}\text { Std. } \\
\text { Deviation }\end{array}$ & 11.87864 \\
\hline \multirow[t]{3}{*}{ Most Extreme Differences } & Absolute & .073 \\
\hline & Positive & .051 \\
\hline & Negative & -.073 \\
\hline Test Statistic & & .073 \\
\hline Asymp. Sig. (2-tailed) & & .200 \\
\hline
\end{tabular}


Tabel 6.Uji Normalitas Kemampuan Berbicara

\begin{tabular}{llr}
\multicolumn{2}{c}{ One-Sample Kolmogorov-Smirnov Test } \\
\hline & & VAR0000 \\
& & 3 \\
\hline $\mathrm{N}$ & & 50 \\
Normal Parameters ${ }^{\mathrm{a}, \mathrm{b}}$ & Mean & 71.0400 \\
& Std. Deviation & 11.39452 \\
Most Extreme Differences & Absolute & .095 \\
& Positive & .091 \\
& Negative & -.095 \\
Test Statistic & & .095 \\
Asymp. Sig. (2-tailed) & & .200 \\
\hline
\end{tabular}

Dari Tabel 5 dan Tabel 6 di atas, diperoleh angka probabilitas atau Asymptotic Sig.(2-tailed)dengan nilai yang sama yaitusebesar 0,200. Nilai ini dibandingkan dengan taraf signifikansi sebesar 0,05 atau 5\%. Dasar pengambilan keputusan dalam uji normalitas, menggunakan pedoman sebagai berikut:

Nilai Sig. atau signifikan atau nilai probabilitas ${ }^{-} 0,05$, maka distribusi data adalah tidak normal.

Nilai Sig. atau signifikan atau nilai probabilitas ${ }^{-}$0,05, maka distribusi data adalah normal

Table 7.Keputusan Uji Normalitas Data

\begin{tabular}{cccc}
\hline Nama & $\begin{array}{c}\text { Nilai } \\
\text { variabel } \\
\text { Sig.(2- } \\
\text { tailed) }\end{array}$ & $\begin{array}{c}\text { Taraf } \\
\text { signifikansi }\end{array}$ & Keputusan \\
\hline $\begin{array}{c}\text { Lingkungan } \\
\text { bahasa arab } \\
\begin{array}{c}\text { Kemampuan } \\
\text { berbicara } \\
\text { bahasa arab }\end{array}\end{array}$ & 0,200 & 0,05 & Normal \\
\hline
\end{tabular}

2) Uji Linearitas

$$
\text { (Sumber: Tabel } 5 \text { dan Tabel 6) }
$$

Untuk mengetahui apakah dua variabel mempunyai hubungan yang linear atau tidak secara signifikan, maka dibuat hipotesis: $H_{0}=$ tidak ada hubungan yang linear secara signifikan antara lingkungan berbahasa Arab dengan kemampuan berbicara, dan $H_{1}=$ ada hubungan yang linear secara signifikan antara lingkungan berbahasa Arab dengan kemampuan berbicara. Untuk menjawab hipotesis, perhatikan hasil perhitungan dengan menggunakan bantuan IBM SPSS Statistics 16 pada Tabel 8 berikut. 
Tabel 8.Uji Linearitas

\begin{tabular}{|c|c|c|c|c|c|c|}
\hline Model & & $\begin{array}{l}\text { Sum of } \\
\text { Squares }\end{array}$ & $\mathrm{df}$ & Mean Square & $\mathrm{F}$ & Sig. \\
\hline \multirow[t]{3}{*}{1} & Regression & 503.178 & 1 & 503.178 & 4.122 & .000 \\
\hline & Residual & 5858.742 & 48 & 122.057 & & \\
\hline & Total & 6361.920 & 49 & & & \\
\hline
\end{tabular}

Berdasarkan Tabel 8 di atas, nampak bahwa nilai Sig sebesar $0,000<$ 0,05 , maka $H_{0}$ ditolak. Hal ini menunjukkan bahwa ada hubungan yang linear secara signifikan antara lingkungan berbahasa Arab dengan kemampuan berbicara.

d. Pembahasan

Berdasarkan data-data yang diperoleh langkah selanjutnya adalah menganalisisnya dengan menggunakan analisis statistik dan analisis kuantitatif. Adapun data yang akan dianalisis adalah hasil dari penyebaran angket lingkungan bahasa Arab dan tes keterampilan berbicara santriwati Pesantren AlAmanah Kecamatan Bungi Kota Baubau tahun ajaran 2017/2018.

Untuk memperoleh analisis, langkah selanjutnya setelah data terkumpul secara lengkap adalah mengklarifikasikan data sesuai dengan proporsinya masing-masing sesuai dengan penelitian ini, yakni:

Untuk bisa mengetahui seberapa besar hubungan lingkungan bahasa Arab terhadap kemampuan berbicara santriwati Pondok Pesantren Al-Amanah digunakan beberapa langkah untuk menjawabnya:

Langkah 1. Membuat Ha dan Ho dalam bentuk kalimat:

Ha : Ada hubungan antara lingkungan Bahasa Arab terhadap kemampuan berbicara bahasa Arab

Ho : Tidak ada hubungan antara lingkungan bahasa Arab terhadap kemapuan berbicara bahasa Arab

Langkah 2. Menganalisis data dengan menggunakan bantuan SPSS 16.

Berdasarkan uji linearitas di atas yang menyatakan bahwa adanya hubungan yang linear, maka untuk mengetahui sejauh mana korelasi antara variabel $(\mathrm{X})$ terhadap variabel $(\mathrm{Y})$ dapat dilihat pada Tabel 9 berikut: 
Tabel 9. Model Summary

Model Summary

\begin{tabular}{llrrr}
\hline $\begin{array}{l}\text { Mod } \\
\text { el }\end{array}$ & $\mathrm{R}$ & R Square & $\begin{array}{c}\text { Adjusted } \\
\text { R Square }\end{array}$ & $\begin{array}{c}\text { Std. Error } \\
\text { of the } \\
\text { Estimate }\end{array}$ \\
\hline 1 & $.481^{\mathrm{a}}$ & .231 & .260 & 4.04795 \\
\hline
\end{tabular}

Dari Tabel 9 di atas, nampak bahwa nilai koefisien korelasi (R) sebesar 0,481. Nilai ini dapat diinterpretasikan bahwa hubungan kedua variabel penelitian berada pada kategori cukup. Sehingga dapat disimpulkan bahwa ada hubungan atau korelasi antara variabel terikat (X) dengan variabel bebas (Y)

Untuk bisa diketahui tingkatsignifikanpengaruhlingkungan bahasa Arab terhadap kemampuan berbicara santriwati Pondok Pesantren Al-Amanah tahun ajaran 2017/2018 digunakan beberapa langkah untuk menjawabnya:

Langkah 1. Membuat Ha dan Ho dalam bentuk kalimat:

Ha : Ada pengaruh yang signifikan antara lingkungan Bahasa Arab terhadap kemampuan berbicara bahasa Arab

Ho : Tidak ada pengaruh yang signifikan antara lingkungan bahasa Arab terhadap kemapuan berbicara bahasa Arab

Langkah 2. Menganalisis data dengan menggunakan bantuan SPSS 16.

Untuk mengetahui sejauh mana pengaruh yang diperkirakan antara lingkungan berbahasa Arab (X) dan kemampuan berbicara (Y), peneliti menggunakan teknik analisis regresi linier sederhana.Lingkungan berbahasa Arab mampu menerangkan variabel kemampuan berbicara, hal ini dapat dilihat pada 4.9. Melalui tabel tersebut diperoleh nilai R Square atau koefisien determin (KD) yang menunjukkan seberapa bagus model regresi yang dibentuk oleh interaksi variabel bebas dan variabel terikat. Nilai KD yang diperoleh adalah 27,9\%. Sehingga dapat ditafsirkan bahwa variabel bebas X memiliki pengaruh kontribusi sebesar $27,9 \%$ terhadap variabel Y.

Untuk menjawab rumusan masalah tersebut, maka perhatikan Tabel 10 berikut.

Tabel 10.Hasil Analisis Regresi

Coefficients $^{\mathrm{a}}$

\begin{tabular}{|c|c|c|c|c|c|}
\hline \multirow[b]{2}{*}{ Model } & \multicolumn{2}{|c|}{$\begin{array}{l}\text { Unstandardized } \\
\text { Coefficients }\end{array}$} & \multirow{2}{*}{$\begin{array}{c}\begin{array}{c}\text { Standardized } \\
\text { Coefficients }\end{array} \\
\text { Beta }\end{array}$} & \multirow[b]{2}{*}{$\mathrm{t}$} & \multirow[b]{2}{*}{ Sig. } \\
\hline & B & Std. Error & & & \\
\hline $\begin{array}{ll}1 \quad \text { (Constant) } \\
\text { arab }\end{array}$ & $\begin{array}{r}94.942 \\
.270\end{array}$ & $\begin{array}{r}11.875 \\
.133\end{array}$ & -.281 & $\begin{array}{r}7.995 \\
-2.030\end{array}$ & $\begin{array}{l}.000 \\
.048\end{array}$ \\
\hline
\end{tabular}


Dari Tabel 10 di atas, tampak bahwa nilai t sebesar 7,995, signifikan pada $0,000<0,05$. Hal ini menunjukkan bahwa $H_{0}$ ditolak. Pada Tabel ini pula, dapat disusun persamaan regresi linier sebagai berikut: $\hat{Y}=94,942+0,270 X$. Persamaan ini menjelaskan bahwa nilai $a=94,942$ (nilai konstanta) apabila tidak ada variabel lingkungan berbahasa Arab, maka kemampuan berbicara sebesar 94,942 dalam artian kemampuan berbicara akan meningkat tanpa adanya variabel lingkunganberbahasa Arab. Sementara nilai $b=0,270$ (nilai koefisien regresi) menunjukkan bahwa setiap variabel kompetensi lingkungan berbahasa Arab meningkat satu kali, dalam artian keterampilan berbicara bahasa Arab akan meningkat sebesar 0,270dengan asusmsi variabel yang lain tetap.

Masalah utama dalam penelitian ini adalah untuk mengetahui apakahlingkungan bahasa Arab (bi'’ah al-'arabiyah) berpengaruh terhadap keterampilan berbicara berbahasa Arab santriwati Pondok Pesantren Al-Amanah. Dari hasil analisis deskriptif data menunjukkan bahwa lingkungan bahasa Arab yang dibentuk oleh Pondok Pesantren Al-Amanah tahun pelajaran 2017/2018 secara umum masih dalam kategori sedang. Hal ini dapat di lihat pada Tabel 2 dimana 9 atau 18\% responden berada dalam kategori tinggi, 33 atau 66\% responden berada pada kategori sedang, dan 8 atau 16\% responden berada pada kategori rendah. Dengan rata-rata atau mean sebesar 88,6000 median sebesar 88,5000 , mode atau modus sebesar 81,00, standar deviasi sebesar 11,87864, nilai minimum sebesar 67,00, nilai maksimum sebesar 120,00 , dan jumlah atau sum sebesar 4430,00.

Sedangkan untuk tingkat kemampuan berbicara bahasa Arab di Pondok Pesantren Al-Amanah tahun pelajaran 2017/2018 secara umum masih dalam kategori sedang pula. Hal ini dapat di lihat pada Tabel 4, dimana 7 atau 14\% responden berada dalam kategori tinggi, 34 atau 68\% responden berada pada kategori sedang, dan 9 atau $18 \%$ responden berada pada kategori rendah. ratarata atau mean sebesar 71,0400, median sebesar 70,0000, mode atau modus sebesar 68,00, standar deviasi sebesar 11,39452, nilai minimum sebesar 48,00, nilai maksimum sebesar 96,00, dan jumlah atau sum sebesar 3552,00.

Berdasarkan hasil analisis data yang dilakukan dengan menggunakan analisis regresi sederhana menunjukkan bahwa lingkungan berbahasa Arab berpengaruh terhadap kemampuan berbicara santriwati di pondok Pesantren AlAmanah. Hal ini dapat di lihat pada Tabel 10, dimana t sebesar 7,995, signifikan pada $0,000<0,05$. Hal ini menunjukkan bahwa $H_{0}$ ditolak, atau $H_{1}$ diterima. Artinya terdapat pengaruh lingkungan berbahasa Arab terhadap kemampuan berbicara santriwati di pondok Pesantren Al-Amanah.

Hasil penelitian ini menjadi bukti keinginan penulis untuk membuktikan bahwa perpaduan bi' 'ah al-'arabiyah dengan penerapan kaedah-kaedah kebahasaan dapat mengantarkan pembelajar/peserta didik untuk mencapai keterampilan berbahasa Arab. Hasil penelitian ini juga menjadi dukungan teori pavlov sebagai pelopor aliran behavioris yang mengemukakan bahwa lingkungan pembelajaran adalah cara yang efektif untuk mencapai kemahiran berbahasa. 
Sekaligus menjadi jawaban atas bantahan yang dilakukan oleh aliran cognitive yang mengatakan bahwa pentingnya keaktifan belajar. Aliran cognitive juga mengemukakan Pembelajarlah yang mengatur dan menentukan proses-proses pembelajaran, lingkungan bukanlah penentu awal dan akhir positif dan negatifnya hasil pembelajaran.

\section{KESIMPULAN}

Berdasarkan hasil analisis kuantitatif data yang telah diujikan, maka dapat disimpulkan bahwa

1. Dari hasil analisis deskriptif data menunjukkan bahwa lingkungan bahasa Arab yang dibentuk oleh Pondok Pesantren Al-Amanah tahun pelajaran 2017/2018 secara umum masih dalam kategori sedang. Hal ini dapat di lihat pada Tabel 2 dimana 9 atau $18 \%$ responden berada dalam kategori tinggi, 33 atau 66\% responden berada pada kategori sedang, dan 8 atau $16 \%$ responden berada pada kategori rendah. Dengan rata-rata atau mean sebesar 88,6000 median sebesar 88,5000, mode atau modus sebesar 81,00, standar deviasi sebesar 11,87864, nilai minimum sebesar 67,00, nilai maksimum sebesar 120,00, dan jumlah atau sum sebesar 4430,00.

2. Kemampuan berbicara bahasa Arabsantriwati di Pondok Pesantren AlAmanah tahun pelajaran 2017/2018 secara umum masih dalam kategori sedang pula. Hal ini dapat di lihat pada Tabel 4, dimana 7 atau $14 \%$ responden berada dalam kategori tinggi, 34 atau $68 \%$ responden berada pada kategori sedang, dan 9 atau $18 \%$ responden berada pada kategori rendah. rata-rata atau mean sebesar 71,0400, median sebesar 70,0000, mode atau modus sebesar 68,00, standar deviasi sebesar 11,39452, nilai minimum sebesar 48,00, nilai maksimum sebesar 96,00, dan jumlah atau sum sebesar 3552,00.

3. Pengelolaan lingkungan bahasa Arab berpengaruh terhadap peningkatan kemampuan lisan berbahasa Arab santriwati pondok pesantren AlAmanah. Dimana nilai t sebesar 7,995, signifikan pada $0,000<0,05$. Hal ini menunjukkan bahwa $H_{0}$ ditolak dan $H_{1}$ diterima, dengan $H_{0}=$ tidak terdapat pengaruh lingkungan berbahasa Arab terhadap kemampuan lisan santriwati pondok pesantren Al-Amanah, dan $H_{1}=$ terdapat pengaruh lingkungan berbahasa Arab terhadap kemampuan lisan santriwati pondok pesantren Al-Amanah.Serta nampak bahwa nilai koefisien korelasi (R) sebesar 0,481, dan koefisien determinasi $\left(R^{2}\right)$ sebesar 0,279. Hal ini menunjukkan bahwa, adanya hubungan antara variabel lingkungan berbahasa Arab terhadap variabel kemampuan lisan santriwati pondok pesantren Al-Amanah. 


\section{DAFTAR PUSTAKA}

'Abd al-Wahịid Wāfí, al-Lugah wa al-Mujtama'(Cairo: Dār Al-Nahḍah, 1997).

A.G. Van Hamel, Sejarah Ilmu Bahasa, diterjemahkan oleh Willie Koen (Flores: Nusa Indah, 1972).

Acep Hermawan, Metodologi Pembelajaran Bahasa Arab.

Ahmad Fuad Effendy, Metodologi Pendidikan Bahasa Arab (Malang: Misykat, 2005).

Ahmad Isa Anshori, Pembudayaan Bahasa Arab di Pondok Pesantren "Nurul Haromain" Desa Ngroto Kecamatan Pujon Kabupaten Malang: Telaah Penumbuhan Biah Arabiyyah (Lingkungan Kearaban,1995).

Azhar Arsyad, Bahasa Arab dan Metode Pendidikannya; Beberapa Pokok Pikiran, (Yogyakarta: Pustaka Peserta didik, 2002).

Azhar Arsyad, Bahasa Arab dan Metode Pendidikannya; Beberapa Pokok Pikiran.

Azyumarid Azra, Pendidikan Islam; Tradisi dan Modernisasi Menuju Milenium Baru (Cet II ; Jakarta: Logos wacana Ilmu, 2000).

Departemen Agama RI, Pola Pengembangan Pondok Pesantren (t.tp., t.th.).

Kementerian Agama Republik Indonesia, al-Qur'an dan Terjemahnya (Jakarta: Ummul Quran, 2017).

Kementerian Agama Republik Indonesia, al-Qur'an dan Terjemahnya.

M. Roqib, Bahasa Arab Dalam Perspektif Gender (Malang: Jurnal Bahasa Arab dan Pendidikannya, 2004).

Naif Ma'rūf, Khașāiṣ al-Lugah al-'Arabiyyah wa Tarìq Tadrīisihā (Beirut: Dar al-Nafais, 2005).

Rian Prakasa Yusuf, "Bahasa Indonesia Sebagai Alat Komunikasi" ryanprakarsayusuf123.blogspot.com. $\quad 15 \quad$ Januari 2013. http://ryanprakarsayusuf123.blogspot.com. (4 April 2015).

Samsuri, Analisis Bahasa (Jakarta : Gelora Aksara Pratama, 2008).

Sulastri, Pengembangan Media Pembelajaran Arabic Thematic Video Pada Keterampilan Berbicara Bagi Peserta didik Kelas Viii MTs, Journal of Arabic Learning and Teaching.

Tim comunity, Bahasa dan Sastra Ensiklomini Pengetahuan Populer (Bandung: Tinta Emas, 2010).

Wa Muna, Metodologi Pembelajaran Bahasa Arab(Yogyakarta: Teras, 2011). 